\title{
Identification of Cavity Zone Under the Surface of the Badut Temple Foundation Using the GPR (Ground Penetrating Radar) Method
}

\author{
Ahmad Luthfin 1,*, Husni Cahyadi², Jufri ${ }^{3}$, Moh Fausi $^{4}$, Aulia Kharisma Nugraha ${ }^{5}$, \\ Dhony Widyasandy 6 \\ ${ }^{1}$ Physics Department, Faculty of Sains and Technology, UIN Maulana Malik Ibrahim Malang, Indonesia \\ ${ }^{2}$ Physics Education Department, Faculty of Tarbiyah and Teacher Science, IAIN Tulungagung, Indonesia \\ ${ }^{3}$ SAINS Department, Faculty of Teacher Training \& Education, Universitas Darussalam Ambon, Indonesia \\ ${ }^{4}$ PGMI Department, Faculty of Tarbiyah, IAIN Madura, Indonesia \\ ${ }^{5}$ Geothermal and Vulkanologi Laboratory, Brawijaya University, Malang, Indonesia \\ ${ }^{6}$ Physics Department, UIN Sultan Maulana Hasanuddin, Banten, Indonesia \\ *Corresponding author. Email: ahmadluthfin@fis.uin-malang.ac.id
}

\begin{abstract}
In the previous research in Badut temple, it resulted in the conclusion that on the research path, there is a Badut temple foundation, at a depth of $0 \mathrm{~m}-1.5 \mathrm{~m}$, which is square wide. The results of this study require further research to detect the presence of a cavity zone because the presence of cavity zones has the potential for subsidence of the temple foundation. This study aims to determine the distribution of cavity zones under the temple foundation. Research in the first location around the temple building was carried out by scanning 8 straight lines, then combined and analyzed. Based on the results of the analysis, it is found that the cavity zones are spread from trajectory 1-8. The largest cavity zone is located in the corner of the intersection of lanes 1 and 2. The second location research was carried out in the pool in front of the temple; the results showed that the pool floor was dominated by the cavity and watery zone. Only a few points showed buried rock, which was shown by reddish-yellow color. Based on the data analysis, it can be concluded that around the temple, there are still many cavity zones, and there are still some buried rocks. As for the pool area, it is dominated by a cavity zone, so it is possible that there is still a lot of empty space under the ground floor of the pool, and it is watery.
\end{abstract}

Keywords: Cavity zones, GPR, Badut Temple

\section{INTRODUCTION}

Badut temple is one of the Hindu-style temples in Malang city. The temple was rebuilt in 1923-1925 AD by the Dutch Indies [1]. In the previous research, it resulted in the conclusion that on the research path, there is a Badut temple foundation, at a depth of $0-1.5 \mathrm{~m}$. The foundation of the Badut temple is square wide. The results of this study require further research to detect the presence of a cavity zone because the presence of cavity zones has the potential for subsidence of the temple foundation [2]. The trajectory in previous research is as shown in Figure 1.
The image produced by the GPR method is a collection of signals obtained from wavelets that have undergone a scattering event with materials that have passed through electromagnetic waves beneath the Earth's surface[3]. 

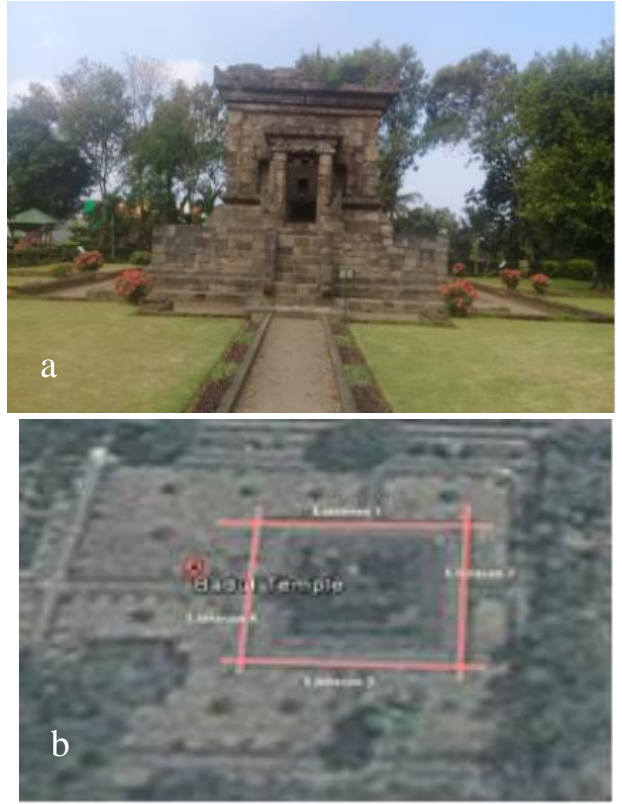

Figure 1 Photo of present Badut temple (a) Photo from google earth of the temple foundation area (b).

This scattering occurs due to the electromagnetic rock properties, which are expressed in the variables of electric permittivity ( $\varepsilon)$, electrical conductivity ( $\sigma$ ), and magnetic permeability $(\mu)$. So in principle, the signal emitted by GPR must have a single frequency and be linearly polarized as follows [4].

$$
\begin{aligned}
& \vec{E}(z, t)=\vec{E}_{o} e^{-\alpha z} e^{i(\omega t-\beta z)} \\
& \vec{B}(z, t)=\vec{B}_{o} e^{-\alpha z} e^{i(\omega t-\beta z)} \\
& \alpha=\omega \sqrt{\frac{\mu \varepsilon}{2}}\left[\sqrt{1+\left[\frac{\sigma}{\mu \varepsilon}\right]^{2}}-1\right]^{1 / 2} \\
& \beta=\omega \sqrt{\frac{\mu \varepsilon}{2}}\left[\sqrt{1+\left[\frac{\sigma}{\mu \varepsilon}\right]^{2}}+1\right]^{1 / 2}
\end{aligned}
$$

Where $\mathrm{E}$ is the electric field (N/C), B is the magnetic field (T), Eo and Bo are the amplitude (complex), $\omega$ the angular frequency, $\alpha$ the attenuation constant $(\mathrm{Np} / \mathrm{m})$, and $\beta$ the phase constant $(\mathrm{rad} / \mathrm{m})$.

Skin depth $(\delta)$ is the depth that the wave passes through where the signal has a reduced amplitude to 1 / e $=0.368=36.8 \%$ of the amplitude at the surface. The depth of penetration is limited by the low conductivity of subsurface rocks or has a high resistance.

$$
\delta=\frac{1}{\alpha}
$$

The electromagnetic radiation reflected by a layer depends on the relative dielectric constant contrast of the adjacent layers. If the contrast is large, the amount of reflected radar wave energy will also be greater [5]. The portion of the reflected energy is expressed as the reflection coefficient $(\mathrm{R})$ determined by the relative dielectric velocity contrast of the medium. In all cases, the magnitude $R$ is in the range \pm 1 . The share of energy transmitted is equal to $1-\mathrm{R}$, while the power of reflection coefficient is equal to $\mathrm{R} 2$. The amplitude of the given reflection coefficient satisfies the equation,

$$
R=\frac{\left(V_{1}-V_{2}\right)}{\left(V_{1}+V_{2}\right)}=\frac{\sqrt{\varepsilon_{1}}-\sqrt{\varepsilon_{2}}}{\sqrt{\varepsilon_{1}}+\sqrt{\varepsilon_{2}}}
$$

Where V1 is the velocity of the radar wave at the first layer, V2 is the velocity of the radar wave at the second layer, and $\mathrm{V} 1<\mathrm{V} 2$. $\varepsilon 1$ and $\varepsilon 2$ are the relative dielectric constant $\left(\varepsilon_{\mathrm{r}}\right)$ of the first layer and the second layer. Whereas the speed of the radar wave through the material depends on the type of material and is a function of the relative permittivity of the material. The velocity of the radar wave in material $(\mathrm{Vm})$ is given by equation [6].

$$
V_{m}=\frac{c}{\left(\left(\frac{\varepsilon_{r} \mu_{r}}{2}\right)\left(\left(1+P^{2}\right)+1\right)\right)^{1 / 2}}
$$

Where $\mathrm{c}$ is the light speed in the air, $\varepsilon$ is the relative dielectric constant, the relative magnetic permeability, $\mathrm{P}$ is the loss factor with. The loss factor indicates the reduction in energy during signal transmission due to absorption by the medium it is passing through. The reduction in energy is actually a transformation or change in the form of energy into heat. In propagation beneath the surface, the waves experience depth penetration, which depends on the electrical, geological properties of the subsurface with the working principle of the sender and receiver pulse waves, so that the subsurface structure will appear due to the presence of subsurface anomalies on the radargram [7].

The system in the GPR method is an active system in which the transmitter is "emitting" electromagnetic wave pulses (at intervals of radar waves), then recording the intensity of the radar waves, which are successfully reflected back to the surface by the receiver [8]. So that the working principle of GPR by utilizing electromagnetic waves that are sent and then reflected because they hit certain objects. The results of this reflection are then recorded [9]. Radar pulses are transmitted, reflected, and scattered by surface structures and subsurface anomalies. The scattered and reflected EM waves are received by the receiving antenna on the earth's surface in the form of a characteristic wave amplitude (radargram) [10]. So that if there is an anomaly in the subsurface layer, we can detect the structure of the layer on the radargram [11]. The working system of the 
GPR tool is in the form of a transmitter, which is an antenna connected to a pulse generator equipped with a timing circuit setting, while the receiver is an antenna connected to the ADC and LNA, which is then connected to the processing unit (data processing) and display as its output display [12].

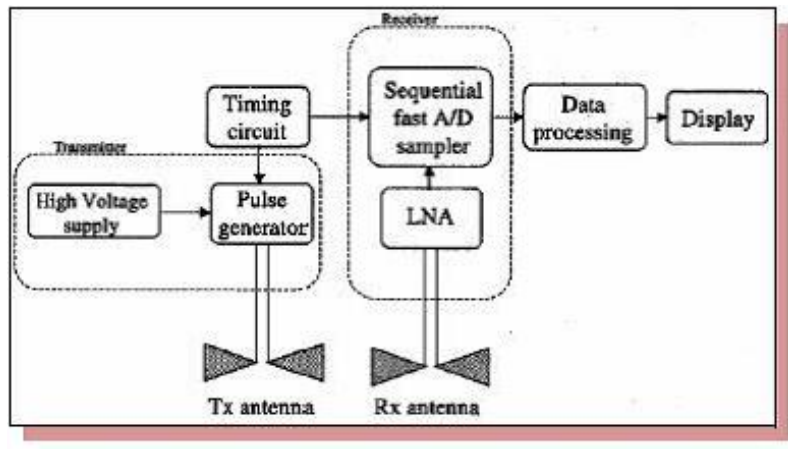

Figure 2 GPR Work System.

Georadar (Ground Penetrating Radar) is very suitable for identification of shallow areas (near-surface) with a depth of fewer than 25 meters, with very high accuracy (resolution), and is able to record data every $2.4 \mathrm{~cm}$, so that sub-surface archaeological objects with dimensions several centimeters can be detected [13]. The advantages of using the GPR method are that it has high resolution and is non-destructive. While the weakness of this method is that the depth of penetration is limited to only a few tens of meters depending on the frequency of the transmitter antenna used. GPR devices can send electromagnetic wave pulses with a frequency between $10-1000 \mathrm{MHz}$ [14]. In some modern systems, they are equipped with an onboard computer that facilitates data processing by obtaining data in the field and postrecording [15].

During its development, the GPR method has been extended to a refractive method [16] and is very good at producing 3D underground structure images [17]. GPR can generate stratigraphic trend conclusions, producing facies images of sediments [18]. This method is able to show the surface of objects buried in the ground, especially in simple geological conditions [19]. The higher the frequency, the higher the signal attenuation in propagation so that the range of the GPR will be shallower [20]. During its development, the ability to identify objects under the surface of the GPR method has become an important tool in the engineering and geophysical environment; as well as widely applied in road quality inspection and detection of bedrock structures, building foundations, shallow soil or rock structures, detecting water levels and water pollution mapping, and many other aspects [21].

\section{METHOD}

The survey design of the GPR method is a straight line around the temple building starting at the coordinates of $7^{\circ}$ 57'27.70 "South Latitude and $112^{\circ} 35 ' 55.71 "$ East Longitude and the temple pool with a specified distance, according to the shape of the temple and the size of the temple according to Figure 2 below.

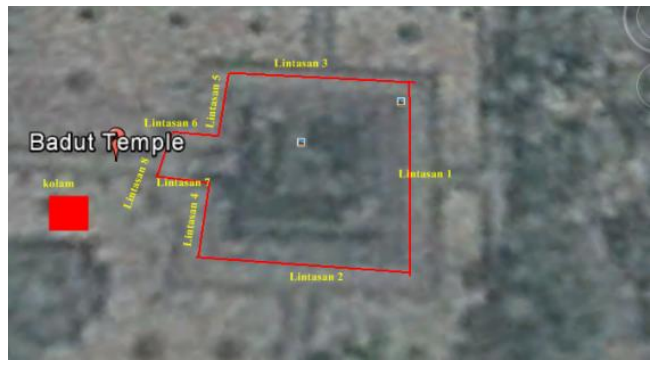

Figure 3 GPR Measurement Line.

Based on Figure 3 above, the red line is the research trajectory using the GPR method. The red square is a pool of water which is located on the left in front of the temple. The research sequence will be carried out according to the research diagram below:

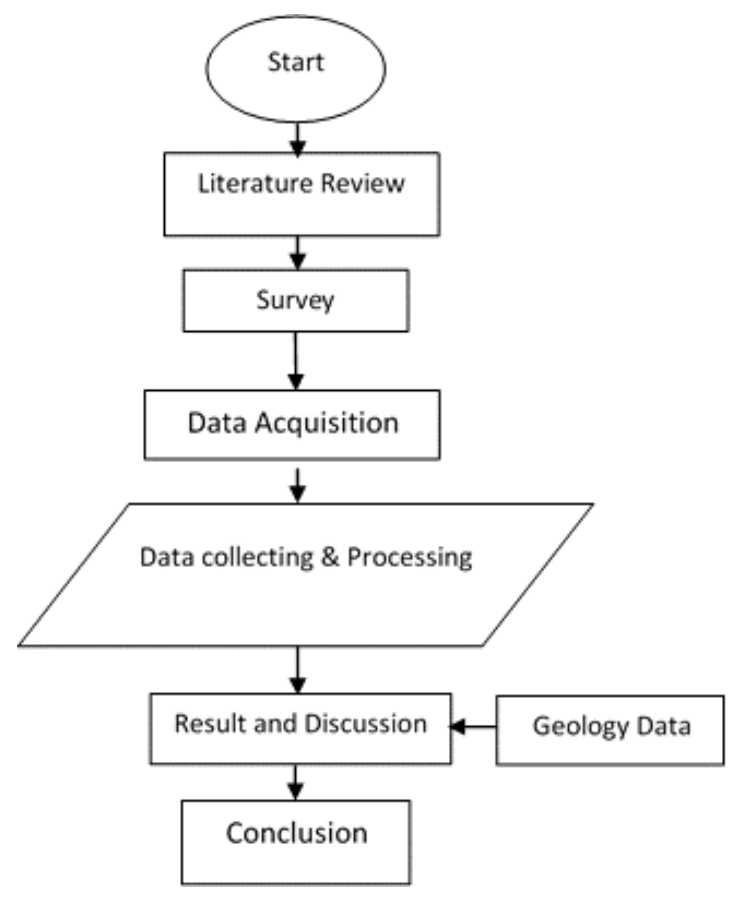

Figure 4 Research Diagram.

\subsection{Data Acquisition}

Data acquisition, by scanning along the research path with a georadar tool slowly and continuously. Radar waves will be transmitted directly below the surface by the transmitter. Then the reflected georadar waves are received by a receiver equipped with a laptop containing data processing software and generating subsurface images. This image is the result of the response from the 
boundary plane (interface) of the surface of the objects and the subsurface layers of the earth, which have different physical and electrical properties. The boundaries between these surfaces are the natural properties of the rock, such as layering, hardening, changes in water humidity, cavities, cracks, and most importantly, the existence of buried rock objects.

The equipment used in the GPR (Ground Penetrating Radar) method is 1 unit of the GPR Future 2005 instrument, which equipped with 3D Software Future 2005

\subsection{Data Collecting and processing}

Radar waves will be transmitted directly below the surface by the transmitter; then, the reflected georadar waves are received by a receiver equipped with a laptop containing data processing software and generating subsurface images. These images are then stored as data, then analyzed and discussed.

GPR data processing aims to produce a good subsurface profile/image with high resolution so that based on this image it can be identified the state and shape of the rock reflector according to the desired target [22]. Processing is done directly (live scan) using 3D software, namely future 2005. This software will immediately display the conditions of the research area through the indicated colors as metal, cavity zones, native soil, and minerals.

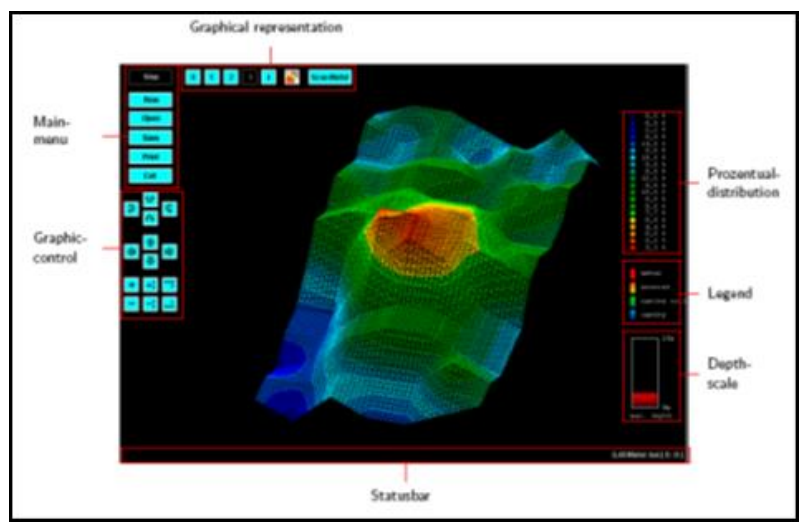

Figure 5 Display of Live Scan Results from Future 2005 Software.

\subsection{Result and Discussion}

Based on the results of the live scan, data interpretation can be made qualitatively on the visualization of the GPR method, which is shown in different colors.

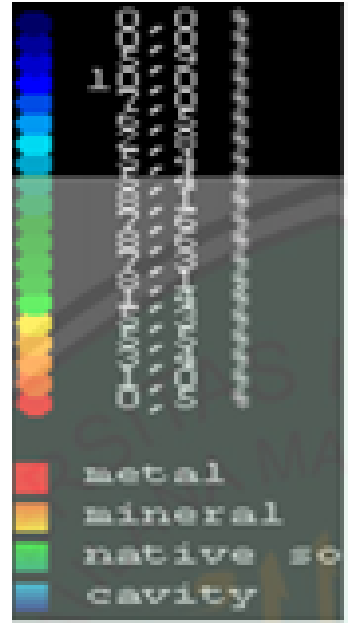

Figure 6 GPR Future Series 2005 Output Color.

Blue indicates the presence of cavities; this cavity zone can be interpreted as the presence of subsurface water that fills the cavities in the area, a weathered layer. Green indicates normal measurements of a surface in the absence of anomalies. The yellow color shows the dry area; the orange color shows the occurrence of mineralization in the soil surface; the red color shows the presence of metals buried in the subsurface. This is as shown in the image below.

Based on Figure 6 shows the color definition at the GPR output. Then the color analysis of the field data is compared with the geological data in the area to obtain information on the possible rock types in the subsurface.

\section{RESULTS AND DISCUSSION}

Based on this research, the Ground Penetrating Radar (GPR) method is used to identify subsurface structures around the temple, the aim is to predict whether the subfoundation structure is compact rock, whether there are still many cavity zones and whether there are still many buried rocks. There are two locations that were measured using GPR, namely the area around the temple and the historical pool in front of the temple. The first location is divided into 8 tracks according to the shape of the temple. The second location is done directly in the pool.

\subsection{Location 1 (lines 1-8)}

Location 1 is the research location around the Badut temple building. Based on the research results, it was found that a shallow subsurface is between $0-3 \mathrm{~m}$ deep. The data obtained is a straight trajectory, the recorded data is directly processed using the Future 2005 software and then the data is combined into one forming the circumference of the temple as shown in Figure 7 below. The following is the research data after being combined into one. 


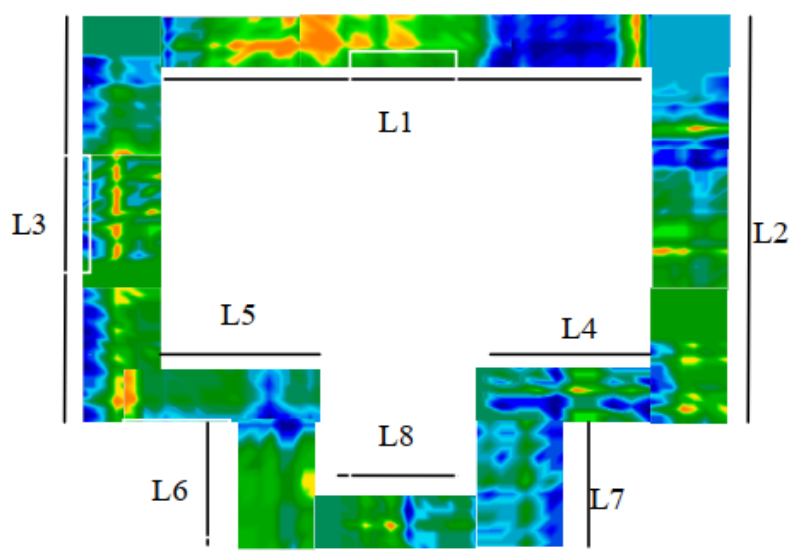

Figure 7. Records of the first location research results.

Based on the recording of research results around the temple, it can be seen that the subsurface structure of the foundation around the Badut temple is based on the color obtained. The reddish-yellow color indicates the presence of metal or rock. Meanwhile, a slightly dark green color indicates that the area is natural soil without anomalies. And the blue color indicates that the area is a cavity. The record that was produced in the first location, around the temple building, was a straight line of 8 lines, then combined and analyzed. Based on the analysis, it is found that the cavity zones are evenly distributed from path 1-8. The largest cavity zone is located in the corner of the intersection of trajectories 1 and 2. For information, there are most buried rocks at trails 1 and 3 . The record shows that around the temple, there are still several empty zones (cavity) which may still have weathered layers and some reddish-yellow spreading, it is possible that there are temple rocks that are still buried, even though their position spreads irregularly. These rocks are thought to be scattered ruins of the temple ruins. This is reinforced by the shape of the temple building, whose top is not intact. Many stones were not found at the time of excavation.

\subsection{Location 2}

Location 2 is the location of the research being carried out in the temple pool, which is in front of the Badut temple. Based on the results of the study, it was found that a shallow subsurface is between $0-3 \mathrm{~m}$ deep. The data obtained is a combination of several straight paths that are formed like a rectangular area. As shown in Figure 8, the recorded data is processed directly using the Future 2005 software. Following are the research data after being processed and combined into one.

Based on the recording at the second location or in the pool area in front of the temple, it shows results that are dominated by dark green and blue colors, and there are several reddish-yellow colors. The green color is identified as soil without any anomalies, and the blue color is identified as the cavity zone. Metal or rock is indicated by a reddish yellow color, which is not so much.

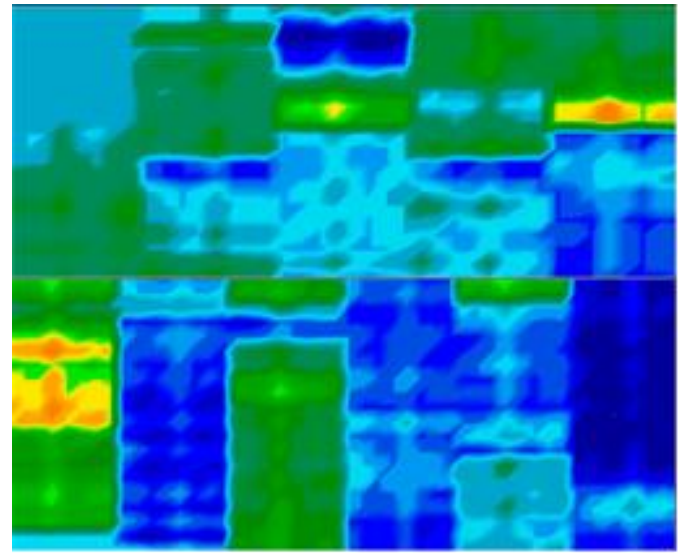

Figure 8. Results of the second location research.

So many cavity zones in the temple pool in front of the Badut temple need restoration to find out and prove the existence of the cavity zone. The cavity zone in this pool contains water visible from the wet ground pool floor. The reddish-yellow color indicates the presence of buried rock, so excavation is necessary to prove the existence of these rocks.

Overall, the results of the subsurface recordings at the first location show that there are still several cavity zones or empty spaces that indicate weathered layers, and there are still some temple rocks (andesite) that are buried in the ground and have not been excavated. However, the distribution of buried rock is very small, mostly dominated by natural soil and cavity zones. The cavity zone here can be estimated as a hole or culvert. The second location is dominated by a cavity zone, so it is possible that there is still a lot of empty and watery space under the ground floor of the pool; only partially there are buried rocks.

\section{CONCLUSION}

Based on the data analysis, it can be concluded that around the temple, there are still many cavity zones, and there are still some buried rocks. As for the pool area, it is dominated by a cavity zone, so it is possible that there is still a lot of empty space under the ground floor of the pool, and it is watery.

\section{AUTHORS' CONTRIBUTIONS}

This research has a differentiating value/novelty compared to previous research because this research was first conducted at the Badut temple. Further research from previous research that proves the existence of a temple foundation extends from the temple building, so it requires cavity zone information so that the temple foundation does not collapse.

The authors' contributions in this research are as follows Data collector:

Ahmad Luthfin, Husni Cahyadi K, Jufri, Moh Fausi, Aulia Kharisma Nugraha, Dhony Widyasandy. 
Report Writer and presenter:

Ahmad Luthfin, Husni Cahyadi K.

\section{ACKNOWLEDGMENTS}

Thank you to the Head of the Mojokerto Cultural Heritage Conservation Center, East Java, who gave permission to conduct this research at Badut temple in Malang city. Thank you to the Head of LP2M UIN Malang, who has provided support by providing opportunities and funding our research reports to attend the ICONETOS 2020.

\section{REFERENCES}

[1] Candi badut, Destinasi Wisata situs sejarah. (2015). Retrieved (maret 16, 2018) from candi badut, destinasi Wisata situs sejarah: https://www.cendananews.com/2015/03/candibadut-destinasi-wisata-situs-sejarah.html

[2] A.Luthfin, 2020, "Identifikasi Batuan Pondasi Candi (andesit)di bawah permukaan sekitar candi badut dengan Metode geolistrik Resistivitas". Indonesian Journal Of Applied Physics, 10(2) (2020) 106-115. DOI: https://doi.org/10.13057/ijap.v10i2.41384

[3] Y. Wahyu, H. Wijanto, "Antena Spiral-dipole untuk Ground Penetrating Radar(GPR)", Jurnal Elektronika dan Telekomunikasi, 13(2) (2013) 3946, DOI: https://doi.org/10.14203/jet.v13.39-46

[4] C.A. Balasnis, Advanced Engineering Electromagnetics, John Wiley and Son, New York, 1989.

[5] A. Kurniati, Buku Panduan : Workshop Geofisika, Laboratorium Geofisika, Jurusan Fisika, Fakultas MIPA, Universitas Brawijaya, Malang, 2008.

[6] J.M. Reynolds, An Introduction to Applied and Environtmental Geophysics. John Wiley and Sons Inc., England, 1997.

[7] S. Aji, “Aplikasi Metode Ground Penetrating Radar Terhadap Pola Retakan Di Bendungan Batu Tegi Lampung". Wahana Fisika, 1(1) (2016) 32-41, DOI: https://doi.org/10.17509/wafi.v1i1.4529

[8] Y. Quan, J.M. Harris, Seismic attenuation tomography using the frequency shift method. Geophysics, 1997, 62, pp. 895-905.

[9] Azizah, "Pemfokusan Citra Radar Untuk Hasil Pemodelan Radar Penembus Permukaan Menggunakan Algoritma Migrasi Jarak", Jurnal TELKOMIKA. 4(1) (2016) 110-122. DOI: https://doi.org/10.26760/elkomika.v4i1.110

[10] D. D. Warnana, "Identifikasi Scouring Sebagai Potensi Kelongsoran Tanggul Sungai Bengawan Solo Berdasarkan Survei GPR (Studi Kasus Desa Widang, Kabupaten Tuban)", Jurnal Fisika dan Aplikasinya, 2008 4(2) (2008) 1-6.
[11] S. Aji, “Aplikasi Metode Ground Penetrating Radar Terhadap Pola Retakandi Bendungan Batu Tegi Lampung”, Jurnal Wahana Fisika, 1(1) (2016) 3241, DOI: https://doi.org/10.17509/wafi.v1i1.4529

[12] B. S. Ayi, Penentuan karakteristik Dinding Gua Seropan Gunungkidul dengan Metode Ground Penetrating Radar, Surabaya, ITS, 2009.

[13] I.M Fadlan, "Georadar In Archaeological Researches Of Indonesia", Balai Arkeologi Kalimantan Selatan, 10(1) (2016).

[14] L. Arkadia, "Dentifikasi Pipa Metal Bawah Permukaan Menggunakan Metode Ground Penetrating Radar (GPR)", PRISMA FISIKA, 7(1) (2019) $20-29 . \quad 29$. http://dx.doi.org/10.26418/pf.v7i1.32286

[15] S. Bijaksana, I. Rusyanti, M.I.T Taib, L.A. Pasasa, A.S. Andreas, "The Use of GPR in Delineating an Iron Sand Boundary and the Determination of Its Electromagnetic Wave Velocity: A Case Study in Jepara, Central Java", Journal of Engineering and Technological Science, 37(2) (2005) 77-90. DOI: http://dx.doi.org/10.5614\%2Fitbj.eng.sci.2005.37.2 .1

[16] R.N. Bohidar \& J.F. Hermance, "The GPR refraction method", Geophysics, 67(5) (2002) pp. 1474-1485.

DOI: https://doi.org/10.1190/1.1512792

[17] M. Grasmueck, R. Weger, \& H. Horstmeyer, "Fullresolution 3D GPR imaging", Geophysics, 70(1) (2005), K12-K19. DOI: https://doi.org/10.1190/1.1852780.

[18] H.M. Jol, D.G. Smith, R.A. Meyers, "Digital Ground Penetrating Radar (GPR): A new geophysical tool for coastal barrier research (examples from the Atlantic, Gulf and Pacific coasts", U.S.A.I. Journal of Coastal Research, 12(4) (1996) 960-968.

[19] J. M. Carcione, "Numerical modeling of GPR electromagnetic fields for locating burial sites". International Conference on Applied Geophysics, E3S Web of Conferences 24, 01002 (2017) DOI: https://doi.org/10.1051/e3sconf/20172401002

[20] J. G. Maloney and G. S.Smith, "A study of transient radiation from the $\mathrm{Wu}$-King resistif monopoleFDTD analysis and experimental measurement", IEEE Trans. Antennas Propagat., 41(5), (1993) 668-679.

[21] S. Liu, Z. Zeng, L. Deng, FDTD Simulations For Ground Penetrating Radar in Urban Applications, Journal Of Geophysics And Engineering, 4, (2007), pp. 262-267. DOI:: https://doi.org/10.1088/1742$2132 / 4 / 3 / \mathrm{S} 04$

[22] S. Astutik, "Penggunaan Ground Penetrating Radar (GPR) sebagai metal Detector", Jurnal ILMU DASAR, MALA Geoscience, Vol. 2 No.1, 1997, PP. 9-16. 